\title{
Effect of dietary L- Carnitine supplementation of diets containing cashew nut reject meal by broiler chicken $\mathrm{S}$
}

A. O. *Fafiolu, A. O. Oso, O. M. O. Idowu, A. V. Jegede, R. A. Sobayo and O. O. Oduguwa College of Animal Science and Livestock Production, Department of Animal Nutrition,

Federal University of Agriculture, P. M. B. 2240, Abeokuta, Nigeria. *Corresponding author: fafiolu2000@yahoo.com, fafioluao@unaab.edu.ng

\section{Abstract}

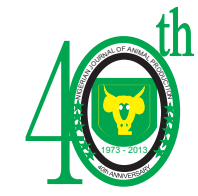

In a completely randomized designed, two hundred and forty day-old broiler chicks were randomly assigned to four dietary treatments containing $0,2.5,5.0$ and $7.5 \mathrm{mg} \mathrm{kg}^{-1} \mathrm{~L}$ carnitine. Each of the diets contained equal amount of maize and cashew nut reject meal (CNRM). The birds were randomly divided into sixteen groups of fifteen chicks each after weight equalisation. Each diet was assigned to four groups of birds representing four replicates per experimental diet. Measurements taken during starting and finishing phases included average live weight, average weight gain, average feed intake while feed to gain ratio was calculated. Nutrient digestibility of the experimental diets was also evaluated. Results between 0-4weeks indicated that body weights ranged from $673.71 \mathrm{~g}$ in the birds that received $2.5 \mathrm{mgkg}-1$ to $700.21 \mathrm{~g}$ in the birds that received $7.5 \mathrm{mgkg}-1 \mathrm{~L}$-carnitine. Weight gain and feed intake values were significantly $(P<0.05)$ affected by L-carnitine levels. Feed to gain ratio values were elevated when birds were fed 0 and $2.5 m g k g-1$ L-carnitine levels. Evaluation of nutrient utilization showed a significant $(P<0.05)$ influence on crude protein and ether extract values. Between 5-8 weeks of rearing, feed intake increased $(P<0.05)$ as Lcarnitine levels increased in diets while lower $(P<0.05)$ feed to gain value was recorded at high level of dietary L-carnitine. Nutrients utilization parameters were not affected $(P>0.05)$ during finishing phase. Overall results showed that highest body weight and weight gain were obtained in the group that received $7.5 \mathrm{mg} \mathrm{kg}^{-1} \mathrm{~L}$-carnitine supplementation. The study showed that supplementing CNRM diets up to $7.5 \mathrm{mg} \mathrm{kg}-1$ is beneficial to growth and utilization of broiler chickens. However, this was more effective at the starter phase.

Keywords: L-carnitine, cashew nut reject meal, broiler birds

\section{Introduction}

Limited supplies of energy feedstuffs as a result of high cost in the poultry sub-sector of the livestock industry in the very recent times had led to non-realization of the objectives of keeping poultry birds especially broilers. Advances in nonruminant nutrition (such as inclusion of exogenous enzymes in diets) had shown improvement in utilization of less known foodstuffs. Such advancement included the addition of single or multi-enzyme to poultry diets to enhance utilisation. Such advancement included the addition of single or multi exogenous enzymes to poultry diets to enhance utilisation of proximate constituents. Cashew nut meal is one of the novel feed resources available that can be regarded as a moderate source of protein and an excellent energy source because of the high fat content (Onifade et at., 1999). Sogunle et al. (2005) opined that addition of Cashew nut reject meal in diets encouraged fat accumulation in broiler which will ultimately reduce quality of 
carcass. The addition of nutritional (use of single or multi-enzyme) and nonnutritional (use of toxic binders) exogenous substances in non-ruminant nutrition is gaining prominence by the day. L-Carnitine is one of such nutritional substances. Carnitine is a quaternary amine $(\beta$ hydroxyl $\gamma$-trimethylaminobutyrate), which is readily soluble in water and found in two stereo isomeric forms, $\mathrm{d}$ - and $\mathrm{L}-$ carnitine (Mc Dowell, 1989). L-Carnitine promotes the mitochondrial b-oxidation of long-chain fatty acids by facilitating their transfer across the inner mitochondrial membrane. It has also been studied that increasing survivability with dietary Lcarnitine supplementation increased overall live yields of broilers without affecting overall performance (Dackiran et al., 2001). This study was designed to investigate the effect of dietary L- carnitine supplementation on cashew nut rejects meal-based diets by broiler chickens in other to assess its efficiency in productive response.

\section{Materials and Methods}

Test Ingredients and diets

The Cashew nut reject meal was obtained from Abodsuccess cashew Processing factory, Ikorodu, Lagos, Nigeria and Lcarnitine was supplied by Lonza Group Ltd, Germany. The CNRM was processed by milling it to $1.0 \mathrm{~mm}$ diameter and incorporated in the diet of broiler to replace $50 \%$ of the energy supplied by maize (Fafiolu, et al., 2007) and was kept constant in other diets. L-carnitine supplementation was done at $0,2.5,5.0$ and $7.5 \mathrm{mg} \mathrm{kg}^{-1}$ (Table 1). Feed was presented to the birds in mash form.

Animal, feeding and management

A total of two hundred and forty (240) unsexed day old broiler chicks of Anak $2000^{\circledR}$ strain were used for the study were obtained from a commercial hatchery. They were weighed and randomly assigned to four dietary treatments. Sixty (60) birds were allocated to each treatment. Each treatment was sub-divided into four replicate groups having fifteen birds each. The chicks were brooded for 2 weeks. Feed and water was made available at all times. The birds were reared on deep litter house with wood shavings as litter materials. This was changed as often as possible as the need arises and the birds were intensively managed.

\section{Data Collection}

Feed intake and body weight of the birds were determined weekly. This was used to evaluate feed to gain ratio at the end of each phases. A record of survivability was also kept.

Metabolic trial

At the end of the starting and finishing phases, two birds whose weights were similar to the mean of each replicate were randomly selected from each replicate and transferred into metabolic cages which had earlier been cleaned and disinfected. The metabolic trial lasted for 6 days made up of a three days acclimatization followed by three days total faecal collection. Record of feed intake and faecal dropping were taken daily. The faecal samples were collected and weighed wet, recorded and oven dried to a constant weight, the weight of dry matter was determined for each replicate.

\section{Chemical analysis}

The proximate and mineral compositions of cashew nut rejects meal, feed and faecal samples were analysed using the procedure described by Association of Analytical Chemists (AOAC, 1990).

Statistical analysis

All data collected were subjected to Analysis of Variance (ANOVA) in a Completely Randomized Design (CRD) using computer software (SAS, 2006). 
Table 1: Proximate composition experimental diets and Cashew nut reject meal $\left(\mathrm{g} \mathrm{Kg}^{-1}\right)$

\begin{tabular}{|c|c|c|c|c|c|}
\hline \multirow{2}{*}{$\begin{array}{l}\text { Proximate } \\
\text { constituents }\end{array}$} & \multicolumn{5}{|c|}{ Levels of L-carnitine supplementation $\mathrm{mgkg}^{-1}$} \\
\hline & 0 & 2.5 & 5.0 & 7.5 & \\
\hline & Diet 1 & Diet 2 & Diet 3 & Di et 4 & CNRM \\
\hline \multicolumn{6}{|l|}{ Starter Diet } \\
\hline Crude Protein & 221.7 & 222.4 & 221.9 & 222.0 & 215.0 \\
\hline Crude Fibre & 34.4 & 38.5 & 37.4 & 36.0 & 50.0 \\
\hline Ether Extract & 90.7 & 90.9 & 90.7 & 90.4 & 42.1 \\
\hline Calcium & 12.0 & 12.1 & 12.1 & 12.1 & 40.0 \\
\hline Phosphorus & 4.0 & 4.1 & 4.1 & 4.1 & 8.7 \\
\hline \multicolumn{6}{|l|}{ Metabolizable } \\
\hline Energy $\left(\mathrm{MJ} \mathrm{kg}^{-1}\right)$ & 13.62 & 13.68 & 13.68 & 13.68 & 21.14 \\
\hline \multicolumn{6}{|l|}{ Finishing Diet } \\
\hline Crude Protein & 210.5 & 215.0 & 214.0 & 215.7 & \\
\hline Crude Fibre & 41.1 & 41.9 & 41.1 & 41.4 & \\
\hline Ether Extract & 110.0 & 110.9 & 100.1 & 101.1 & \\
\hline Calcium & 11.6 & 11.6 & 11.6 & 11.6 & \\
\hline Phos phorus & 3.9 & 3.8 & 3.8 & 3.8 & \\
\hline \multicolumn{6}{|l|}{ Metabolizable } \\
\hline Energy $\left(\mathrm{MJ} \mathrm{kg}^{-1}\right)$ & 13.10 & 13.11 & 13.14 & 13.10 & \\
\hline
\end{tabular}

Significant differences were separated using Duncan multiple range test of the same package.

\section{Results and Discussion}

Results of proximate analysis revealed that cashew nut reject meal contained $21.50 \%$ crude protein and $42.10 \%$ Ether extract. The values recorded for crude fibre, ash and nitrogen free extract were $0.5,33.0$ and $22.5 \%$ respectively. Result also showed that cashew nut reject meal contains more Phosphorus than calcium. The result obtained in this study is at variance with an earlier report of Ojewola et al. (2004) that cashew nut reject meal contained crude protein content of $38.12 \%$ and $16 \%$ for ether extract. However the elevated value of ether extract reported in this study may be due to the fact that the cashew nut reject meal used was full fat. However, the determined crude fibre contents of the cashew nut reject meal obtained in this trial was slightly at variance with the findings of Fetuga et al. (1975) who reported a crude fibre content of $1.50 \%$. Various factors ranging from the processing method, length of storage, and storage facility, the type of soil on which the crop was grown and different types of species may have been responsible for such variations (Ojewola $e t$ al.,2004). The performance characteristics of starter broiler fed experimental diets are presented in Table 2. The highest body weight and weight gain were obtained on birds fed diet four $\left(7.5 \mathrm{mgkg}^{-1}\right.$ levels of Lcarnitine) while birds on diet $1\left(0 \mathrm{mgkg}^{-1}\right.$ level of L-carnitine) recorded the lowest value. Average weight gains were significantly $(\mathrm{P}<0.05)$ increased as the level of dietary L-carnitine supplementation increased. However, feed intake was significantly $(\mathrm{P}<0.05)$ lowered at the starter phases across the dietary treatment. The 
Table 2: Performance of starting and finishing broilers fed L-carnitine supplemented Cashew nut reject meal diets

\begin{tabular}{|c|c|c|c|c|c|}
\hline \multirow[b]{2}{*}{ Measurements } & \multicolumn{5}{|c|}{ Level of L-carnitine supplement ation $\mathrm{mgkg}^{-1}$} \\
\hline & 0 & 2.5 & 5.0 & 7.5 & SEM \\
\hline \multicolumn{6}{|l|}{$\begin{array}{l}\text { Starting Phase (1- } \\
\text { 4wks) }\end{array}$} \\
\hline Initial weight (g) & 39.50 & 39.50 & 40.30 & 38.60 & 0.22 \\
\hline $\begin{array}{l}\text { Average body } \\
\text { weight (g) }\end{array}$ & 673.71 & 670.74 & 700.1 & 700.21 & 0.66 \\
\hline $\begin{array}{l}\text { Average weight gain } \\
\text { (g) }\end{array}$ & $200.15^{\mathrm{e}}$ & $200.10^{c}$ & $250.12^{\mathrm{b}}$ & $270.86^{\mathrm{a}}$ & 1.76 \\
\hline $\begin{array}{l}\text { Average feed intake } \\
\text { (g) }\end{array}$ & $492.41^{\mathrm{a}}$ & $491.41^{\mathrm{a}}$ & $462.12^{\mathrm{b}}$ & $442.12^{\mathrm{b}}$ & 1.25 \\
\hline Feed to gain ratio & $2.46^{\mathrm{a}}$ & $2.45^{\mathrm{a}}$ & $1.84^{\mathrm{b}}$ & $1.63^{\mathrm{b}}$ & 0.16 \\
\hline Survivability & 100.00 & 100.00 & 100.00 & 100.00 & 0.00 \\
\hline $\begin{array}{l}\text { Finishing Phase (5- } \\
\text { 8wks) }\end{array}$ & & & & & \\
\hline Initial weight (g) & 673.71 & 670.74 & 700.1 & 700.21 & 0.66 \\
\hline weight $(\mathrm{g})$ & 2200.00 & 2200.00 & 2000.00 & 2310.00 & 2.75 \\
\hline $\begin{array}{l}\text { Average weight gain } \\
\text { (g) }\end{array}$ & $1999.85^{\mathrm{a}}$ & $1529.26^{\mathrm{c}}$ & $1509.9^{c}$ & $1608.79^{b}$ & 12.24 \\
\hline $\begin{array}{l}\text { Average feed intake } \\
(\mathrm{g})\end{array}$ & $669.00^{\mathrm{b}}$ & $669.12^{\mathrm{b}}$ & $660.56^{\mathrm{b}}$ & $755.55^{\mathrm{a}}$ & 2.16 \\
\hline Feed to gain ratio & $2.98^{\mathrm{a}}$ & $2.28^{\mathrm{b}}$ & $2.28^{\mathrm{b}}$ & $2.12^{\mathrm{a}}$ & 0.21 \\
\hline Survivability & 100.00 & 100.00 & 100.00 & 100.00 & 0.00 \\
\hline
\end{tabular}

feed intake of bird fed on the lowest level of L-carnitine $\left(0 \mathrm{mgkg}^{-1}\right.$ level of L-carnitine) was significantly higher than of birds fed on the highest level of L-carnitine $\left(7.5 \mathrm{mgkg}^{-1}\right.$ levels of L-carnitine). The feed to gain ratio values obtained in this study were significantly $(\mathrm{P}<0.05)$ higher at the lower L-carnitine levels. Higher levels of Lcarnitine recorded reduced values. The broilers may have been able to use better the Cashew nut reject meal diets due to the presence of supplemental dietary Lcarnitine. At this stage of experiment there was no negative impact on survivability $(\mathrm{P}<0.05)$. During the finishing stage, broilers fed experimental diets showed that higher body weight was obtained in the birds on diet 4 while birds on other diets results in similar final weight. However the average weight gain did not show a particular trend though a progressive reduction of the gain was recorded up till 5.0 mgkg-1 L-carnitine supplementation. This result agrees with earlier findings of Rabies and Szillagyi (1998) that reported the highest level of weight gain at the control diet and realized lower level of weight gain at the medium stage and there is a little elevation at the final dietary treatment. However the feed intake values were not affected between the control diet and 2.5 and $5.0 \mathrm{mgkg}^{-1}$ level of L-carnitine 
Table 3: Apparent nutrient metabolisability of broiler chickens fed L-carnitine supplemented Cashew nut reject $m$ eal diets during starter and finisher phases

\begin{tabular}{|c|c|c|c|c|c|}
\hline \multirow[b]{2}{*}{ Measurements } & \multicolumn{5}{|c|}{ Level of L-carnitine supplementation $\mathrm{mgkg}^{-1}$} \\
\hline & 0 & 2.5 & 5.0 & 7.5 & SEM \\
\hline \multicolumn{6}{|l|}{ Starting } \\
\hline Dry matter & 68.11 & 69.11 & 69.39 & 69.76 & 1.32 \\
\hline Crude protein & $60.12^{\mathrm{c}}$ & $60.25^{\mathrm{c}}$ & $65.00^{\mathrm{b}}$ & $71.00^{\mathrm{a}}$ & 3.58 \\
\hline Crude fibre & 60.12 & 62.20 & 69.12 & 70.80 & 0.01 \\
\hline Ash & 66.57 & 66.70 & 65.50 & 60.50 & 0.01 \\
\hline Ether extracts & $79.12^{\mathrm{b}}$ & $83.10^{\mathrm{a}}$ & $84.26^{\mathrm{a}}$ & $85.12^{\mathrm{a}}$ & 0.01 \\
\hline Nitrogen extracts & 86.62 & 85.10 & 86.62 & 86.10 & 0.16 \\
\hline \multicolumn{6}{|l|}{ Finisher } \\
\hline Dry matter & 70.87 & 70.60 & 73.12 & 72.11 & 0.14 \\
\hline Crude protein & 60.71 & 63.12 & 62.1 & 64.26 & 0.57 \\
\hline Crude fibre & 81.14 & 80.00 & 82.19 & 81.94 & 0.12 \\
\hline Ash & 70.40 & 73.10 & 72.50 & 72.65 & 0.26 \\
\hline Ether extracts & 86.85 & 86.26 & 85.10 & 86.10 & 0.14 \\
\hline Nitrogen extracts & 88.89 & 87.10 & 89.12 & 89.95 & 0.11 \\
\hline
\end{tabular}

Means on the same row having different superscripts are significantly different $(\mathrm{P}<0.05)$

SEM: Standard error mean

but significantly $(\mathrm{P}<0.05)$ increase at the final level of L-carnitine $\left(7.5 \mathrm{mgkg}^{-1}\right.$ level of L-carnitine). The feed to gain ratio observed in this study were significantly $(\mathrm{P}<0.05)$ increase at the control diet $\left(0 \mathrm{mgkg}^{-1}\right)$ but decrease as the level of dietary L-carnitine supplementation increased.

Nutrient metabolisability of the experimental broilers at starting phase showed that dry matter metabolisability was not significantly $(\mathrm{P}>0.05)$ different across the treatments (Table 3). However, metabolisability of crude protein and ash and metabolisability of ether extract and crude fibre were significantly $(\mathrm{P}<0.05)$ increased as L-carnitine supplementation increased. The highest $(\mathrm{P}<0.05)$ dry matter metabolisability was recorded when the broilers were fed $5.0 \mathrm{mgkg}^{-1} \mathrm{~L}$-carnitine at the finishing stage. Crude protein and ash metabolisability were increased as the dietary L-carnitine levels increased. Fat metabolisability of CNRM diets at this phase were not affected across the treatments. The observed increase in weight gain and metabolisability values might be a result of increased b-oxidation activity in the test birds on CNRM diets. L-carnitine is essential in energy metabolism, and especially for the b-oxidation of long chain fatty acids. Our findings are in agreement with the results of Daskiran and Teeter (2001), that dietary L-Carnitine supplementation may have beneficial effects on the broiler nutrition status presumably due to its sparing effect on amino acids like lysine and methionine. Also Rabie and Szillagyi (1998) reported that dietary carnitine caused significant increases in nutrient utilization. The observation of elevated metabolisability values noted at the two phases showed that L-carnitine is effective in enhancing nutrient utilization especially fat.

\section{Conclusion}

The study showed that supplementing CNRM diet up to $7.5 \mathrm{mgkg}^{-1}$ is beneficial to broiler both at the starting and finishing 
phases. It inclusion in the diets of broiler is therefore advocated. Further research work is also necessary be done on the nutritive value of L-carnitine for other poultry species especially pullets and layers. Lcarnitine supplementation of other high energy feed ingredients should also be studied.

References

AOAC. 1990. Official methods of Analysis. Association of official Analytical Chemists $15^{\text {th }}$ Ed. Washington, DC.

Daskiran, M. and R.G. Teeter. 2001. Effects of Dietary L-carnitine supplementation on overall performance and carcass, characteristics of Seven week old Broiler chickens, Animal Science Research Report. P: 1-5.

Fetuga, B.L Babatunde, G.M. and Oyenuga, V.A. 1975. The feeding stuff potential of cashew nut scrap kernel meal. Proc. Of Tropical products institute on Animal feeds of Tropical nad subtropical origins. Tropical products institute, London (UK) P: 208-214.

McDowell, L.R. 1989. Vitamins in animal nutrition, $2^{\text {nd }}$ edition, Academic press
Inc.San Diego C.A.

Ojewola, A.S.F, Okoye, C. and Agbak, I. 2004. Replacement Value of Cashew nut meal for soyabean meal in finishing Broiler chicken. Int.J. of Poultry Science 3 (8), p: 513-516.

Onifade, A.A, Odunsi A.A, Babatunde, G.M, Olorede, B.R. and Muma, E. 1999. Comparism of the supplemental effects of Sacharomyces cerevisea and antibiotics in low protein and high fibre diets fed to broiler chickens. Arch Anim. 52:29-39.

Rabie, M.M. and M. Szillagyi. 1998. Effect of L-carnitine supplementation of diets differing in energy levels on performance, abdominal fat content and yield composition of edible meat of broilers. Br. J. Nutri.; 80:391-400.

SAS Institute. 2006. SAS/STAT User's Guide. Release 9.1. SAS Inst. Inc., Cary, NC.

Sogunle, O.M., Fanimo, A.O., Biobaku, W.O. and Bamgbose, A.M. 2005. The feeding value of full-fat cashew nut (Anacardium occidentale) rejects and low cereal diets for broiler chickens. Nig. J. Anim. Prod. 32(1): 46-53.

Received: $11^{\text {th }}$ October, 2011 Accepted: $25^{\text {h }}$ Septem ber, 2012 